\title{
Identifying the Factors Contributing to Students' Difficulties in the English Language Learning
}

\author{
Nor Hani Misbah¹, Maslawati Mohamad², Melor Md Yunus², Azizah Ya'acob³ \\ ${ }^{1}$ Sekolah Kebangsaan Pekan Dua, Wilayah Persekutuan Labuan, Malaysia \\ ${ }^{2}$ Faculty of Education, Universiti Kebangsaan Malaysia, Bangi, Malaysia \\ ${ }^{3}$ Pusat Citra Universiti, Universiti Kebangsaan Malaysia, Bangi, Malaysia \\ Email: honeymyst396@gmail.com
}

How to cite this paper: Misbah, N. H., Mohamad, M., Md Yunus, M., \& Ya'acob, A. (2017). Identifying the Factors Contributing to Students' Difficulties in the English Language Learning. Creative Education, $8,1999-2008$.

https://doi.org/10.4236/ce.2017.813136

Received: August 14, 2017

Accepted: October 9, 2017

Published: October 12, 2017

Copyright (c) 2017 by authors and Scientific Research Publishing Inc. This work is licensed under the Creative Commons Attribution International License (CC BY 4.0).

http://creativecommons.org/licenses/by/4.0/

\begin{abstract}
In today's ever-changing world, the English language has been placed to be one of the important languages in communication, as well as the main medium of instruction in education. To be in line with this acknowledgement, the Ministry of Education of Malaysia has placed the importance of mastering the English language and has highlighted the need for students to excel in the language as early as in the primary school years. To reach this aim, the Ministry of Education has introduced the GPMP (Gred Purata Mata Pelajaran/ Subject Grade Point Average) target for English to schools in every state to ensure every school performs well in the subject. However, there are still a handful of schools that are unable to pass this GPMP target for English due to the poor performance of their students in the subject. Therefore, this study aims to investigate the factors that interfere with the students'performance in learning English. The participants of this study were the 116 students from the seven schools that were unable to reach the state's GPMP in the English language. This study used questionnaire as the instrument to explore the factors that hindered them from performing well in the subject. Overall, the findings show that there are three major themes that contribute to the students' difficulties in the English language learning; the lack of English vocabulary, the influence of the first language and the socio-economic status of the family. The findings and discussion of this study would be able to help the pertinent parties such as teachers, school administrators and parents to make decisions for the learners 'improvement in their English language learning.
\end{abstract}

\section{Keywords}

Factors, EFL, Difficulties, Primary School, Students 


\section{Introduction}

In today's ever-changing world, the English language has been placed to be one of the important languages in communication, as well as the main medium of instruction in education worldwide. To be in line with this acknowledgement, the Ministry of Education of Malaysia placed the importance of mastering the English language and has highlighted the need for students to excel in the language in the primary school years. To reach this aim, the Ministry of Education has introduced the GPMP (Gred Purata Mata Pelajaran/Subject Grade Point Average) target for English to schools in every state to ensure every school performs well in the subject.

However, there are still a handful of schools that are unable to pass this GPMP target for English according to SISC+ Labuan (SISC+ Labuan, 2016) due to the poor performance of their students in the subject. As a matter of fact, the final score of the school's overall GPMP will affect the school's GPK (Gred Purata Keseluruhan/Overall Grade Point Average), which in turn, influences the school's position in the national ranking. According to The Economic Planning Unit (The Economic Planning Unit, 2012) Unit as stated in the 10th Malaysia Plan, all schools in Malaysia are assessed and ranked according to their performance bands annually.

In respect to the mastery of English proficiency and its relation to the Malaysian context, Jalaluddin, Mat Awal, \& Abu Bakar (2008) claimed that there are challenging constraints in comprehending the English language in Malaysia. In this case, however, there have been reports that many EFL students are lack of EFL reading proficiency and thus are not able to read and understand well materials in the English language (David \& Govindasamy, 2006; Stapa et al., 2007). Therefore, with inadequate ability to comprehend the words they are reading they are unable to answer comprehension questions, and follow instructions. In addition, with limited vocabulary, they also face difficulties to express themselves in spoken English. These limitations adversely affect the students' achievement in English, resulting in poor performance in the subject. The Labuan state's passing GPMP target for English in the 2015 UPSR was set at 2.95. There were 7 schools that failed to meet the aforementioned target, indicating the students' poor performance in English as the cause that impedes these schools from obtaining the stipulated pointer.

Therefore, the aim of this study is to investigate the factors affecting the students' performance in English. This study utilised a questionnaire instrument adapted from a previous research Mohamad Nor et al. (2015). The participants of this research were the 116 Year 6 students from seven Sekolah Kebangsaan (National) schools that failed to achieve the state's GPMP (Gred Purata Mata Pelajaran/Subject Grade Point Average) target for English Language. After the research was carried out, the researchers were able to identify several factors that contribute to the students'difficulties in English language learning. 


\section{Literature Review}

This study investigates the factors that contribute to the students' difficulties in learning the English language from the students' perspective as the previous study done by Mohamad Nor, Mazlan, \& Rajab (2015) focused on the teachers' perspective. Generally, teaching the second language to those who are not exposed to the atmosphere of the target language is challenging. Most of them do not use the language in their daily life and often encounter the use of target language only in school and within the classroom of the target language. Teaching English (as the second language) is indeed a great task for the teachers (Jalaluddin et al., 2008). In fact, the task of teaching English as the target language becomes more difficult in remote areas as the local settlers communicate among each other using their ethnic dialects. In the context of this research, teachers posted to remote areas often find themselves incapable of communicating with the students as they could not comprehend the patois. This is supported by Pal, Halder, \& Guha (2016) that ineffective classroom communication occurs when learners and teachers is not at the same level of understanding, which thus, hinders the messages to be conveyed by the teachers in classroom activities. The choice to use the national language-Bahasa Malaysia-also presents a different kind of challenge: most of the students themselves are not proficient Bahasa Malaysia speakers. In this situation, the learners would perceive that the second language is difficult and impossible for them to learn. Hence, this perception will influence the learning outcome, a phenomenon similar to Bernat \& Gvozdenko (2005) claimed on how the learners' conceptualisations on their learning will either facilitate or hinder their language learning activity.

In relation to enhancing the children's vocabulary of the target language, Goodson et al. (2009) highlighted the role of parents, teachers and society in helping these young children build a larger vocabulary through support and exposure to the target language. While giving the children opportunities to communicate in the target language is good, they can also help improve the children's vocabulary through meaningful reading. According to Abdul Gafoor \& Remia (2013), children will be more confident in speaking and writing in the target language if they have a wide range of vocabulary. Being unable to express their own thinking in a target language effectively will demotivate the learners to use it in their daily life. As asserted by Embi \& Mohd Amin (2010), it is essential for language learners to have a wide range of vocabulary as it helps them communicate effectively in the language. Hence, an enhanced vocabulary improves the learner's confidence and their motivation to practise and learn more about the language.

Motivation to learn a foreign or second language can also be attributed to how fun and interactive the experience can be. According to Mohamed (2013), the learners' academic achievement does depend on their level of motivation in learning. Thus, the English language teachers should be creative and innovative in lessons to attract the learners' attention and nurture positive motivation towards learning the language. As far as the social cognitive theory is concerned, 
Lam (2016) affirmed that students'intrinsic motivation to learn and speak English could be developed through various types of activities conducted by the teacher. Through these activities, the students can gain knowledge inside and outside the classroom spheres, learning through fun activities as well as enjoying a stress-free environment. According to Charles (2011), children tend to engage in activities that please them. Therefore, as the students enjoy the activities, they would also benefit by learning the language. Furthermore, Sillanpää (2012) verified that it is undeniable that motivation gives a great impact on how well a certain language is learned. Therefore, this study tried to explore the factors that contribute to the students'difficulties in learning the English language from the students 'perspective. It is important to look into local primary students' perspective on their language learning difficulties because only by doing so appropriate measures to rectify or reduce the learning difficulties could be proposed. According to Louis \& Melor (2016), learning English in Malaysian context particularly in rural areas in East Malaysia is unique because it is used as a foreign language by the students. In this aspect, the students only learn English inside the classroom and hardly use it in their daily conversation. In addition, teachers are trained to teach English as a second language, thus, there is a mismatch between the teachers' training and expectation with the reality. Therefore, the findings could enlighten educators in designing their activities particularly for students who have similar characteristics.

\section{Research Methodology}

\subsection{Research Setting and Participants}

A total of 116 Year 6 students from seven Sekolah Kebangsaan (National) schools that failed to achieve the state's GPMP (Gred Purata Mata Pelajaran/ Subject Grade Point Average) target for English Language subject were chosen as the participants of this study. They were selected according to their proficiency in the English language with the help of the respective school 's English subject teacher. They were the low achievers in the English language subject. Additionally, these students volunteered to participate in the research. The research used the Labuan State's GPMP (Gred Purata Mata Pelajaran/Subject Grade Point Average) target of 2015 UPSR for English subject which is 2.95 (SISC+ Labuan, 2016) as benchmark to select the schools. Table 1 shows the profile of the participants of the study. The participants comprise of 62 male and 54 female students. Out of these 116 students, 79 are Malays, 35 are Bumiputra Sabah \& Sarawak and 2 are non-citizens. There was no racial discrimination throughout the lessons and research. In Malaysian context, it is typical that the composition of students is mixed and having non-citizen in the classroom. Mixed marriage is also common in Malaysia.

\subsection{Research Instrument}

The instrument used in this study was a questionnaire, adapted from a previous 
Table 1. Profile of participants by frequency and percentage.

\begin{tabular}{cccc}
\hline Construct & Category & Frequency & Percentage \\
\hline \multirow{2}{*}{ Gender } & Male & 62 & 53.45 \\
& Female & 54 & 46.55 \\
\multirow{2}{*}{ Race } & Malay & 79 & 68.10 \\
& Chinese & 0 & 0.00 \\
& Indian & 0 & 0.00 \\
& Bumiputera Sabah & 28 & 24.14 \\
& Bumiputera Sarawak & 7 & 6.03 \\
& Non-citizen & 2 & 1.72 \\
\hline
\end{tabular}

research by Mohamad Nor et al. (2015). The items were adapted to suit the participants who were primary school students. The items were also translated to Bahasa Malaysia as it is the medium of instruction of all the participating schools. The items in the questionnaire were also tested to the students to see whether they were clear and understandable. This is in accordance with Idris' (2013) suggestion that emphasises the use of a simple and clear vocabulary and the use of specific language the respondents are familiar with in the instrument building.

The questionnaire was designed to obtain data on basic demographic profile (gender, grade obtained in the most recent examination, parents 'level of education and their monthly income), the participants' interest and motivation towards learning the English language, the language aspects in relation to Bahasa Malaysia, social aspects in relation to the participants' social environment and the participants' own views and suggestions. This questionnaire applied a 3 likertscale as the participants are primary school students; thus, it is easier for them to express their views as they can choose to either agree, not agree or if they rather be neutral. This is also supported by Chua (2011) who asserted that instrument should be short and simple to avoid respondents being confused by the items. Additionally, the Smileys were also added to the questionnaire to represent the scale of "Agree;" "Uncertain;" and "Disagree" as Chua (2011) also suggested the use of illustration in the instrument to attract the respondents 'interest. All the information gathered from the questionnaire was analyzed using Statistical Package of Social Sciences (SPSS).

\section{Findings and Discussion}

The findings are discussed in three major themes identified from the study: the lack of English vocabulary, the influence of the first language and the socioeconomic status of the family.

\subsection{The Lack of English Vocabulary}

Embi \& Mohd Amin (2010) explained that it is essential for foreign language learners to have a wide range of vocabulary as it helps them to communicate ef- 
fectively in the target language. As stated in Table 2, having limited range of English vocabulary had caused the students to face difficulties in acquiring the four language skills: listening, speaking, reading and writing. The listening skill recorded the highest mean (2.46), which is congruent with what Gilakjani \& Sabouri (2016) claimed: students face difficulties in understanding a conversation taken place in a target language as it is often disregarded in the classrooms as most teachers focus more on other skills.

With all the skills affected by the limited range of vocabulary, it can be derived that the biggest obstacle faced by the students in learning the English language is their limited vocabulary. This finding confirms the previous study's findings, which claims that a limited vocabulary of the English language is the biggest difficulty for ESL learners (Mohamad Nor, Mazlan, \& Rajab, 2015). Additionally, they also explored that learners face difficulties due to lack of vocabulary, especially in listening and speaking skills. According to Stapa, Abu Bakar, \& Abdul Latiff (2007) besides writing skills, which are affected by limited range of vocabulary, they also asserted that having deficient range of vocabularies causes poor written literacy as the students face problems in details and cohesion of the ideas. It is because the meaning is hardly conveyed due to the inaccuracy of the language used in their written task.

Table 2. Issues in Relations with Limited English Vocabulary.

\begin{tabular}{ccccc}
\hline Issue & Agree & Uncertain & Disagree & Mean \\
\hline $\begin{array}{c}\text { Inability to understand conversations in English } \\
\text { Inability to speak in English conversations }\end{array}$ & 73 & 23 & 20 & 2.46 \\
$\begin{array}{c}\text { Inability to understand content in English reading } \\
\text { materials }\end{array}$ & 70 & 28 & 28 & 2.23 \\
Inability to write good English essays & 58 & 47 & 11 & 2.45 \\
\hline
\end{tabular}

Table 3. Issues in Relation with the Influence of the First Language.

\begin{tabular}{|c|c|c|c|c|}
\hline Issue & Agree & Uncertain & Disagree & Mean \\
\hline Bahasa Malaysia is easier to understand than English & 98 & 18 & 0 & 2.84 \\
\hline $\begin{array}{l}\text { Achievement in the Bahasa Malaysia subject is } \\
\text { better than English subject }\end{array}$ & 83 & 32 & 1 & 2.71 \\
\hline $\begin{array}{l}\text { The grammar of Bahasa Malaysia is } \\
\text { easier to comprehend }\end{array}$ & 82 & 33 & 1 & 2.70 \\
\hline $\begin{array}{c}\text { The differences between the grammatical } \\
\text { structures of Bahasa Malaysia and English } \\
\text { language are confusing }\end{array}$ & 69 & 31 & 16 & 2.46 \\
\hline More confidence in speaking using Bahasa Malaysia & 83 & 26 & 7 & 2.67 \\
\hline $\begin{array}{c}\text { More interest in reading Bahasa Malaysia reading } \\
\text { materials as they easier to comprehend }\end{array}$ & 94 & 18 & 4 & 2.78 \\
\hline $\begin{array}{l}\text { Inability to understand English reading materials due } \\
\text { to confusing English grammatical structures }\end{array}$ & 64 & 35 & 17 & 2.41 \\
\hline
\end{tabular}




\subsection{The Influence of the First Language}

As shown in Table 3, students obtained better marks in Bahasa Malaysia subject with the mean score of 2.84 and showed more interest in reading materials in Bahasa Malaysia (mean: 2.78) or speaking in Bahasa Malaysia (mean: 2.67). This is due to the perception that Bahasa Malaysia's grammatical structures are easier to understand (mean: 2.70) compared with the English grammatical structures (mean: 2.41), which forbids the students to embrace the meaning of the words both in written and spoken forms. Bahasa Malaysia differs from English in many aspects, which often causes the inability to be proficient in both languages, especially for the second and foreign language learners. Labuan state, despite being inhabited by people of various ethnicity and diverse cultures, the majority of speakers still maintain Bahasa Malaysia as their first language. In this context, Jalaluddin, Mat Awal, \& Abu Bakar (2008) pointed out that the morphological and syntactical differences between Bahasa Malaysia and English are illustrated to be one of the main factors causing the students to have difficulties in mastering the English language. Cai (1993) also agreed that the differences resulted in grammatical errors in writing and incorrect idea presentation. Furthermore, Mohamad Nor, Mazlan, \& Rajab (2015) also included in their study that learners show problems in writing English essays as they are unable to produce grammatically correct pieces of writing thus hindering them to successfully communicating and conveying their ideas across.

\subsection{The Socio-Economic Status of the Family}

Table 4 below shows the monthly income of the students 'parents. As portrayed, $79.31 \%$ of the students come from the families with monthly income of less than RM 2, 999. According to the Department of Statistics Malaysia (2015), the median monthly household income for the Labuan State is RM 5,684 which indicates that the students 'family income falls below the expected income level considering the current economic state in the country and Labuan itself, which is a growing industrial state. It can be argued that this affects the family's capacity to fulfill the educational demands such as sending their children for tuition classes and buying reading materials for them. Besides, Willingham (2012) perceived that parents with high financial capital could provide to their children better access and learning opportunities. This statement also agrees with Jalaluddin, Mat Awal, \& Abu Bakar (2008: 109) who stated that "the combination of factors

Table 4. Monthly income of the students' family.

\begin{tabular}{ccc}
\hline Income & Number & Percentage (\%) \\
RM 5000 and above & 9 & 7.76 \\
RM 3000 - RM 4999 & 15 & 12.93 \\
RM 1000 - RM 2999 & 50 & 43.10 \\
RM 999 and less & 42 & 36.21 \\
\hline
\end{tabular}


such as poverty, lack of tuition services, social environment, interests and attitudes contribute to the inability of students to acquire English". In this perspective, another factor that contributes to the challenging environment of teaching and learning the second language is the parental involvement. With the increase in the cost of living and the rise of living standards, most families tend to have both parents working to support the living cost. Hence, parents become too busy to get involved with their children's matters especially about the children's school matters, Omar \& Esa (2008) affirmed that parents and school play a significant role in determining the learners 'academic achievement. Thus, it is vital that the school cooperate with the learners' parents in order to nurture improvement in the learners' academic achievement especially in their language learning progress. In context, Blok, Peetsma, \& Roede (2007) also pointed out in their meta-analysis that the schools believe that with better understanding of the school's aims and methods, closer parental involvement will occur, hence resulting positive increment in their children's development. Besides, Yahya (2005) also added that the learners' achievement would be more meaningful when their family members show their concern and participate in the process towards the learners'success. In the context of language learning, United Kingdom Department for Children, Schools and Families (DCSF) (2008) portrayed the support for parental involvement by stating that positive attainment can be seen in the children's scores for pre-reading, language as well as for numbers.

\section{Conclusion and Implications}

The biggest factor that contributes to the students' difficulties in learning English is the limited vocabulary. Students with limited vocabulary find themselves struggling to read, write, listen and speak in English. This is congruent with what Goodson Layzer, Simon, \& Dwyer (2009) affirmed-young children build a larger vocabulary from the language used by the people around them. Therefore, pertinent parties, especially teachers and parents should work on the strategies and activities that can help the learners to enhance their English vocabulary. The influence of the first language also contributes to the children's demotivated state to learn English as a second language. The fact that Bahasa Malaysia's structure is the students' first language thus it is more comprehensible and familiar further solidifies the argument. As a recommended solution to address this difficulty, educators should identify the first language influence and provide explicit explanation particularly on the differences of language structure and grammar of both languages to tackle those problems. The language teaching and learning however should avoid dull lessons in order to spark the students' interest and motivation. Interactive elements in English lessons such as game-changer attract the learners to be more interested in learning the language. Besides, the school administrators, together with the teachers and parents can provide a relaxed learning environment to the learners as it improves learners' motivation to learn the language (with fun reading and listening materials in English) and overcome their inhibitions to converse in it. Lastly, the findings in- 
dicate that students from a low income background perform poorly in English subject. The parents' meager earnings means limited access to extra English classes, English reading materials and an English-speaking environment. Thus, another possible solution to cope with this matter, it is implored that the school administrators work with the teachers to organise tuition classes for these students as well as raise donations for them to buy English learning materials to help them improve their English skills and proficiency level.

There are a few limitations of this study. The study was conducted in schools that were unable to pass the state's GPMP target for the English language subject in Labuan, Malaysia and only limited to the 116 low-achievers of the English language subject from all the 7 schools. In the future, it is suggested that more studies should be conducted to identify factors affecting students' difficulties in learning the English language in a broader geographical location, diverse learning environment, various race. The current research provides the information on the factors and reasons contributing to students' difficulties in the English language learning. Therefore, it is suggested that a bigger sample size should be employed for future study. Besides, it is also recommended that the future study to utilise the sample from high-achievers in the English language subject to obtain richer data for the study as well as able to make vital comparisons on the reasons and the factors that influence the students' achievement and proficiency in the target language. Apart from that, the current study utilized a quantitative approach and data collection was through questionnaire. Thus, for future research, it is proposed that qualitative research approach is used as well. This can be done by conducting a semi-structured interview with the students, observation as well as document analysis in order to gain bigger corpus to study the factors and reasons contributing to students'difficulties in the English language learning.

\section{References}

Abdul Gafoor, K., \& Remia, K. R. (2013). Influence of Phonological Awareness, Morpho Logical Awareness and Non-Verbal Ability on Reading Comprehension in Malayalam. Guru Journal of Behavioral and Social Sciences, 1, 128-158.

Bernat, E., \& Gvozdenko, I. (2005). Beliefs about Language Learning: Current Knowledge, Pedagogical Implications, and New Research Directions. TESL-EJ, 9, 1-21.

Blok, H., Peetsma, T. D., \& Roede, E. (2007). Increasing The Involvement of Parents in The Education of Special-Needs Children. The British Journal of Developmental Disabilities, 53, 3-16.

Cai, G. (1993). Beyond bad writing: Teaching English composition to Chinese ESL students (pp. 2-24). Paper presented at the College Composition and Communication Conference. San Diego, CA.

Chua, Y. P. (2011). Kaedah Penyelidikan. Selangor: McGraw Hill (Malaysia) Sdn. Bhd.

Charles, C. (2011). Building Classroom Discipline (10th ed.). Boston: Pearson Education.

David, M. K., \& Govindasamy, S. (2006). National Identity and Globalization in Malaysia. In A. B. M. Tsui, \& J. W. Tollefson (Eds.), Language Policy, Culture, and Identity in Asian Contexts, (pp. 55-72). Lawrence Erlbaum: Mahwah, New Jersey.

Department of Statistics, Malaysia (2015). Report of Household Income and Basic Amen- 
ities Survey 2014. Putrajaya: Department of Statistics, Malaysia.

Embi, M. A., \& Mohd Amin, M. Z. (2010). Strategies for Successful English Language Learning (SELL). Shah Alam: Karisma Publications Sdn. Bhd.

Goodson, B., Layzer, C., Simon, P., \& Dwyer, C. (2009). Developing Early Literacy: Report of the National Early Literacy Panel. Washington: National Institute for Literacy.

Gilakjani, A. P., \& Sabouri, N. B. (2016). Learners’Listening Comprehension Difficulties in English Language Learning: A Literature Review. English Language Teaching, 9, 123-133. https://doi.org/10.5539/elt.v9n6p123

Idris, N. (2013). Penyelidikan Dalam Pendidikan. Selangor: McGraw Hill (Malaysia) Sdn. Bhd.

Jalaluddin, N. H., Mat Awal, N., \& Abu Bakar, K. (2008). The Mastery of English Language among Lower Secondary School Students in Malaysia: A Linguistic Analysis. European Journal of Social Sciences, 7.

Lam, R. N. K. (2016). The Effectiveness of using Songs Incorporated with Other Activities to Increase Students'Motivation and Confidence to Speak English in an EFL Environment. Education Study Series, No. 11/12, 124-141.

Louis, M. M., \& Melor, M. Y. (2016). Issues Contributing to Low Performance of English in a National School in Song Sarawak. In Proceedings of International Seminar on Generating Knowledge through Research. Universiti Utara Malaysia.

Mohamad Nor, F., Mazlan, M. H., \& Rajab, A. (2015). English Language Teachers'Perceived Difficulty of English Skills Faced by ESL Learners. Journal of Advanced Research in Social and Behavioural Sciences, 1, 12-18.

Mohamed, N. (2013). Komitmen ibu bapa menerusi PIBG dalam membantu pencapaian akademik pelajar. [Parents' Commitment in Parent-Teacher Association to Help Students' Academic Achievement.] Masters Thesis, Universiti Tun Hussein Onn Malaysia.

Omar, Z., \& Esa, A. (2008). Persepsi guru terhadap hubungan pihak sekolah dengan ibu bapa: Proposal. [Teachers' Perception towards Parent-School Relationship.] In Seminar Kebangsaan Pengurusan Pendidikan. Universiti Tun Hussein Onn Malaysia.

Pal, N., Halder, S., \& Guha, A. (2016). Study on Communication Barriers in the Classroom: A Teacher's Perspective. Online Journal of Communication and Media Technologies, 6, 103-118.

Sillanpää, J. (2012). Motivational Strategies as Perceived and Implemented by Future L2 Teachers. Master's Thesis, Jyväskylä University, Finland.

SISC+ Labuan (2016). Carta GPMP Bahasa Inggeris UPSR 2015 Sekolah-Sekolah Di Wilayah Persekutuan Labuan. [GPMP Chart of English Subject for Primary School Evaluation Test (UPSR) in Labuan.] Labuan: SISC+ Labuan.

Stapa, S. T., Abu Bakar, N., \& Abdul Latiff, R. (2007). Literasi Penulisan Bahasa Inggeris Dalam Kalangan Pelajar Luar Bandar: Implikasi Terhadap Pengajaran Dan Pembelajaran. [Literacy on English Written Texts among Rural Students: Implications towards Teaching and Learning.] Jurnal e-Bangi, 2.

The Economic Planning Unit (2012). Tenth Malaysia Plan. Putrajaya: Prime Minister's Department.

United Kingdom Department for Children, Schools and Families (DCSF) (2008). The Impact of Parental Involvement on Children's Education. DCSF Publications.

Willingham, D. T. (2012). Why Does Family Wealth Affect Learning? In American Educator (pp. 33-39). Berlin: Spring.

Yahya, E. (2005). Pendidikan Teknik dan Vokasional Di Malaysia. [Technical and Vocational Education in Malaysia.] Selangor: IBS Buku Sdn. Bhd. 